Revista Brasileira de Agricultura Irrigada v.11, nº.5, p. 1693 - 1699, 2017

ISSN 1982-7679 (On-line)

Fortaleza, CE, INOVAGRI - http://www.inovagri.org.br

DOI: $10.7127 /$ rbai.v11n500750

Protocolo 750.17 - 23/05/2017 Aprovado em 31/08/2017

\title{
SOFTWARE FOR MANAGING LOCALIZED IRRIGATION SYSTEMS IN FRUIT TREES
}

\author{
Bismarc Lopes da Silva ${ }^{1}$, Marcelo Rocha dos Santos ${ }^{2}$, Naasoom Luiz Santos \\ Mesquita $^{1}$, Poliana Prates de Souza Soares ${ }^{1}$
}

\begin{abstract}
SUMMARY
We developed a computer program for managing localized irrigation schedules, which is based on the crop evapotranspiration (ETc). The reference evapotranspiration (ETo) can be estimated by the FAO's standard method, Penman-Monteith, and by four more alternative methods (Priestley-Taylor, Jesen-Haise, Hargreaves-Samani and Class A evaporation pan) in case the user does not have all the necessary climatic variables for estimating the ETo by the standard method. The program estimates the crop coefficient (Kc) of fruit trees, such as mango, banana, papaya, grape, guava, passion fruit, and citrus, which are commonly grown fruits in the Semiarid of Bahia. It allows estimating the daily irrigation run time of these crops, not being restricted, however, to them. The application was developed in Object Pascal programming language through the integrated development environment (IDE) Lazarus 1.6, which enabled the creation of a simple and friendly interface, as well as accurate calculation routines.
\end{abstract}

Keywords: Drip irrigation, evapotranspiration, irrigation management

\section{SOFTWARE PARA MANEJO DE SISTEMAS DE IRRIGAÇÃO LOCALIZADA EM FRUTEIRAS}

\begin{abstract}
RESUMO
Desenvolveu-se um programa de computador para manejo de irrigação localizada com base na evapotranspiração da cultura (ETc). A evapotranpiração de referência (ETo) pode ser estimada pelo método padrão da FAO, Penman-Monteith, e por mais quatro métodos alternativos (Priestley-Taylor, Jesen-Haise, Hargreaves-Samani e Tanque Classe A) caso o usuário não disponha de todas as variáveis climáticas necessárias para a estimativa pelo método padrão. O software estima o coeficiente da cultura $(\mathrm{Kc})$ das fruteiras manga, banana, mamão, uva, goiaba, maracujá, e citros, frutas comumente produzidas no semiárido baiano, o que possibilita a estimativa do tempo de irrigação diário dessas

\footnotetext{
${ }^{1}$ Undergraduate student, Instituto Federal Baiano, BA, Régis Pacheco St. 82, CEP 46.430-000, Guanambi, BA. Phone (77) 991743150.email: bismarctra@gmail.com; nasommesquita@yahoo.com; poliana_prate@hotmail.com.

${ }^{2}$ PhD, Professor, Instituto Federal Baiano, Guanambi, BA. marrochas@yahoo.com.br.
} 
culturas, não sendo restrito, porém, a essas fruteiras. O aplicativo foi desenvolvido em linguagem Object Pascal por meio do ambiente integrado de desenvolvimento Lazarus 1.6, o que possibilitou a criação de uma interface simples e amigável, assim como precisão nas rotinas de cálculo.

Palavras-chave: Gotejamento, evapotranspiração, manejo de irrigação

\section{INTRODUCTION}

Crop irrigation is currently considered to be a great economical alternative for Brazil, especially for its northeastern region; however, fresh water resources should be used rationally, by using appropriate techniques for water, soil and crop management (Silva et al., 2005). Therefore, localized irrigation, as it is more efficient, is the recommended method in terms of water use efficiency.

Localized irrigation is a watering method that has as its main pros the application of water close to the plant roots and the lower usage of water due to its higher application efficiency (Maia \& Levien, 2010); thus, the interval between applications should be as short as possible so as to maintain the soil moisture around the root system close to the field capacity (Mantovani, et al., 2012). Accordingly, a daily irrigation schedule is a good alternative to meet the water needs of orchards, particularly, in sandy soils, as these soils store smaller amounts of water than those with higher clay content.

After choosing a daily irrigation schedule, managing it is a great challenge for small farmers who usually irrigate their orchards improperly. For this reason, the usage of computers is necessary to find the right amount of water to apply, and one way to find it is by estimating the reference evapotranspiration (ETo).

As the computer science advances, several programs were developed for making the process of estimating the ETo a simpler task. Miranda et al. (2005) developed an electronic spreadsheet for aiding the farmers in adequately managing their cashew orchards. Similarly, Paula et al. (2002) developed a system for irrigation management, though it was intended to mango trees. Other researchers followed the same steps by developing electronic spreadsheets for irrigation management, without specifying, however, the crop. (Nascimento et al., 2012; Silva et al., 2013).

The program IrriManga (Santos, 2013) was developed for managing mango trees irrigated by localized irrigation in the semiarid of Bahia state; nevertheless, as it is limited to mangoes, this program is less useful for farmers who grow other kind of fruit crop, so it should be improved upon. Therefore, we aimed to develop a computer program for managing localized irrigation systems, focusing on fruits commonly grown in the semiarid by small farmers.

\section{MATERIAL AND METHODS}

The application IrriFruit was developed in Object Pascal using the Integrated Development Environment (IDE) Lazarus ${ }^{\circledR}$, which is an alternative to Delphi ${ }^{\circledR}$. Lazarus ${ }^{\circledR}$ has an open code and runs on the main operational systems, such as Windows, Linux and Mac.

The estimation of the irrigation run time is based on the reference evapotranspiration (ETo). IrriFruit can estimate the ETo through five methods: Penman-Monteith (FAO's standard method), Priestley-Taylor, JesenHaise, Hagreaves-Samani and Class A evaporation pan. The selection of each method depends on the weather variables that are available to the user.

The Penman-Monteith method (Allen et al., 1994) is the FAO's standard method, which requires the solar radiation, average humidity, maximum and minimum temperature and average wind speed. If the solar radiation cannot be measured in the field, this variable can be estimated, following the FAO's recommendation (1998), by Hargreaves radiation equation (Hargreaves; Allen, 2003) (02). 


$$
\text { ETo }=\frac{0,408 \Delta\left(\mathrm{R}_{\mathrm{n}}-\mathrm{G}\right)+\gamma\left(\frac{900 \mathrm{U}_{2}}{\mathrm{~T}+273}\right)\left(\mathrm{e}_{\mathrm{s}}-\mathrm{e}_{-}\right)}{\Delta+\gamma\left(1+0,34 \mathrm{U}_{2}\right)}(01)
$$

which means,

ETo - reference evapotranspiration, $\mathrm{mm} \mathrm{day}^{-1}$

$\mathrm{R}_{\mathrm{n}}$ - net radiation at the crop surface, $\mathrm{MJ}^{-}$

${ }^{2}$ day $^{-1}$

$\mathrm{G}$ - soil heat flux density, $\mathrm{MJ} \mathrm{m}^{-2}$ day $^{-1}$

$\mathrm{T}$ - mean daily air temperature, ${ }^{\circ} \mathrm{C}$

$\mathrm{U}_{2}$ - wind speed at $2 \mathrm{~m}$ height, $\mathrm{m} \mathrm{s}^{-1}$

$\mathrm{e}_{\mathrm{s}}$ - saturation vapor pressure, $\mathrm{kPa}$

$\mathrm{e}_{\mathrm{a}}$ - actual vapor pressure, $\mathrm{kPa}$

$\Delta$ - slope vapor pressure curve, $\mathrm{kPa}^{\circ} \mathrm{C}^{-1}$

$\gamma$ - psychrometric constant, $\mathrm{kPa}^{\circ} \mathrm{C}^{-1}$.

$$
\mathrm{R}_{\mathrm{s}}=\operatorname{kRs}\left(\mathrm{T}_{\max }-\mathrm{T}_{\min }\right)^{0,5} \mathrm{Ra}
$$

which means,

$\mathrm{R}_{\mathrm{s}}-$ Solar radiation, $\mathrm{MJ} \mathrm{m}^{-2} \mathrm{day}^{-1}$

$\mathrm{R}_{\mathrm{a}}$ - Extraterrestrial radiation, $\mathrm{MJ} \mathrm{m}^{-2} \mathrm{~d}^{-1}$

$\mathrm{T}_{\max }$ - Maximum air temperature, ${ }^{\circ} \mathrm{C}$

$\mathrm{T}_{\text {min }}$ - Minimum air temperature, ${ }^{\circ} \mathrm{C}$

kRs - Adjustment coefficient, 0.16 for interior

locations and 0.19 for coastal locations, ${ }^{\circ} \mathrm{C}^{-0.5}$.

If the wind speed variable is missing, the evapotranspiration can be estimated by Priestley-Taylor equation (1972) (03), which is a simplification of the Penman-Monteith method.

$$
\text { ETo }=1,26 \times\left[\frac{\Delta}{\gamma+\Delta} \times(\mathrm{Rn}-\mathrm{G})\right] \times 0.408
$$

which means,

ETo - reference evapotranspiration, $\mathrm{mm}_{\text {day }}{ }^{-1}$

$\mathrm{R}_{\mathrm{n}}$ - net radiation at the crop surface, $\mathrm{MJ} \mathrm{m}^{-}$

${ }^{2}$ day $^{-1}$

$\mathrm{G}$ - soil heat flux density, $\mathrm{MJ} \mathrm{m}^{-2}$ day $^{-1}$

$\Delta$ - slope vapor pressure curve, $\mathrm{kPa}^{\circ} \mathrm{C}^{-1}$

$\gamma$ - psychrometric constant, $\mathrm{kPa}^{\circ} \mathrm{C}^{-1}$.

If both the wind speed and average humidity are missing, the ETo can be estimated by Jesen-Haisen method (1963) (04).

$$
\text { ETo }=R_{s}\left(0,025 \times T_{\text {ave }}+0,078\right) \times 0.408
$$

which means,

ETo - reference evapotranspiration, $\mathrm{mm} \mathrm{day}^{-1}$

$\mathrm{R}_{\mathrm{s}}$ - solar radiation, $\mathrm{MJ} \mathrm{m}^{-2} \mathrm{day}^{-1}$

$\mathrm{T}$ - mean daily air temperature, ${ }^{\circ} \mathrm{C}$.

Among the weather variables, maximum and minimum temperatures are the ones most likely to be available to small farmers. If it is the case, the following method can be used (Hargreaves-Samani, 1985):

$$
\text { ETo }=0.0009384(\mathrm{~T}+17,8)\left(\mathrm{T}_{\max }-\mathrm{T}_{\min }\right)^{0,5} \mathrm{R}_{\mathrm{a}}
$$

which means,

ETo - reference evapotranspiration, $\mathrm{mm} \mathrm{day}^{-1}$ $\mathrm{T}$ - mean daily air temperature, ${ }^{\circ} \mathrm{C}$

Class A pan is a method still commonly used among small producers, as it is simple to use and requires few calculations to estimate the ETo (Doorenbos \& Pruitt, 1977).

which means,

$$
\text { ETo }=\text { Epa } \times \text { Kp }
$$

ETo = reference evapotranspiration, $\mathrm{mm} \mathrm{day}^{-1}$ $\mathrm{Epa}=$ water evaporated from the pan, $\mathrm{mm}_{\text {day }^{-1}}$ $\mathrm{Kp}=$ Pan coefficient.

$\mathrm{Kl}=$ Localized coefficient
$\mathrm{T}_{\max }$ - maximum air temperature, ${ }^{\circ} \mathrm{C}$

$\mathrm{T}_{\min }$ - minimum air temperature, ${ }^{\circ} \mathrm{C}$

$\mathrm{R}_{\mathrm{a}}$ - extraterrestrial radiation, $\mathrm{MJ} \mathrm{m}^{-2} \mathrm{~d}^{-1}$

After obtaining the ETo, the irrigation time is calculated by using the equation recommended by Goodwin at al. (2000) (07).

$$
\mathrm{I}_{\mathrm{t}}=\frac{\text { ETo } \times \mathrm{Kc} \times \mathrm{K}}{\mathrm{q} \times \mathrm{S}_{1} \times \mathrm{S}_{2} \times \mathrm{L}}
$$

which means, $\mathrm{I}_{\mathrm{t}}=$ Irrigation run time, $\mathrm{h}$ ETo $=$ reference evapotranspiration, $\mathrm{mm}_{\text {day }}{ }^{-1}$ Kc $=$ Crop coefficient $\mathrm{q}=$ emitter discharge, $\mathrm{dm}^{3} \mathrm{~h}^{-1}$ 
$\mathrm{S} 1$ = Spacing between plants within the row, $\mathrm{m}$ $\mathrm{S} 2$ = Spacing between row of plants, $\mathrm{m}$ $\mathrm{Ef}=$ Application efficiency, decimal.

The localized coefficient is calculated by IrriFruit, whereas the crop coefficient can be either manually inputted or estimated. For the latter option, the stage in which the crop is must be informed

\section{RESULTS AND DISCUSSION}

Most computer applications for irrigation management are designed for users who are familiar with the subject, such as researchers, agronomists, professors, and students. Conversely, small farmers need simpler programs in order to make the use of such applications more widespread. Considering it, we developed a straightforward program, in which the user is not overwhelmed by several data-input screens, as depicted in Figure 1.

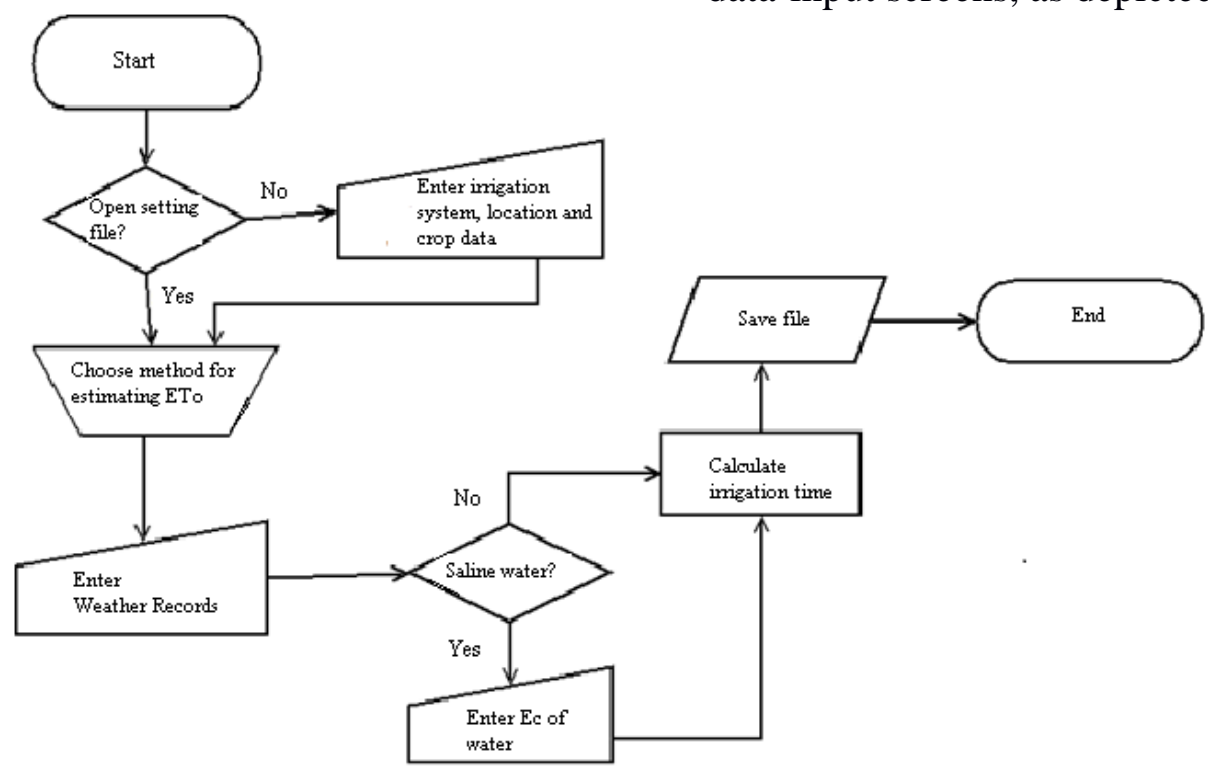

Figure 1. Flowchart of the IrriFruit's alghorith.

The IrriFruit's main screen and its toolbar can be seen in Figure 2 and 3, respectively. All the unchangeable data throughout the production cycle can be saved for later use, such as flow rate and number of emitters, altitude and spacing.

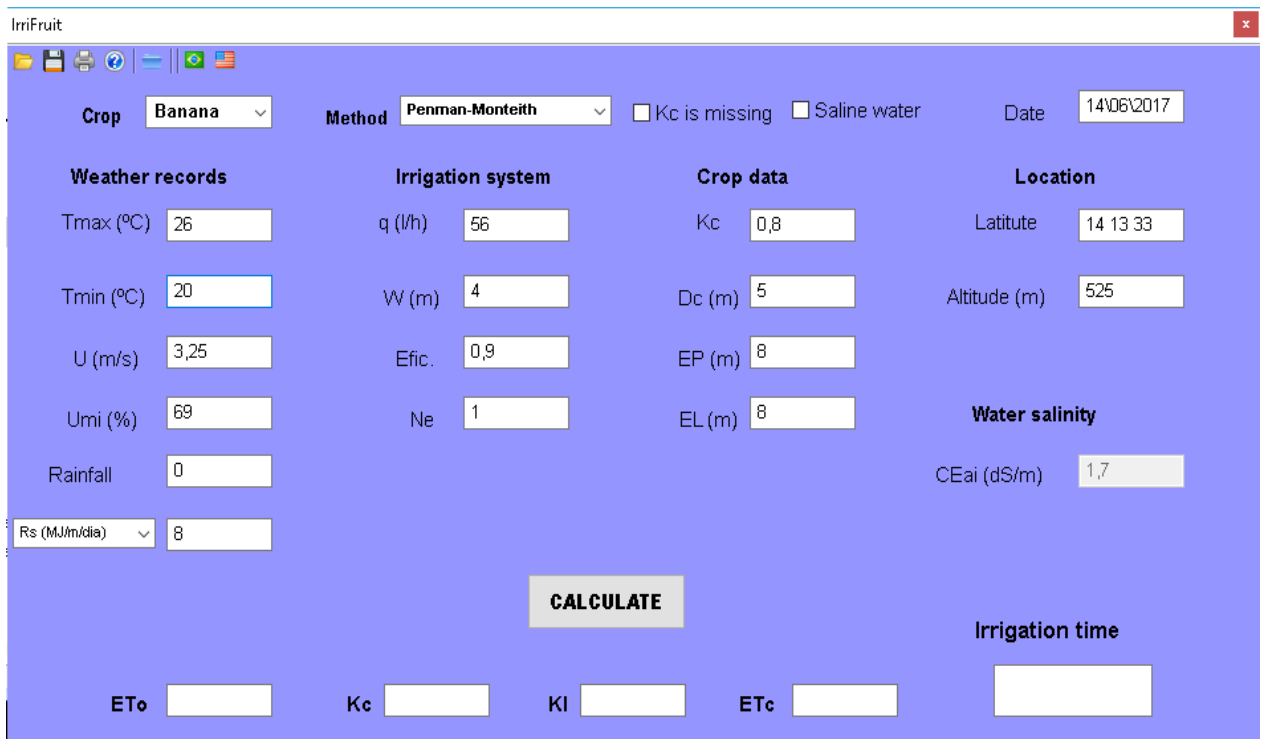

Figure 2. Main screen of IrriFruit. 


\section{IrFiFruit.}

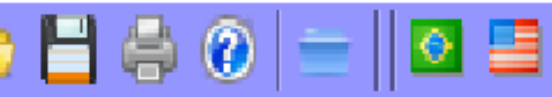

Figure 3. Toolbar of IrriFruit. Name of the buttons from left to right: open setting file, save current setting, report, help, Class A pan, select language Portuguese or English.

The user can choose among four methods for estimating the reference evapotranspiration (ETo), among which Penman-Monteith is the standard method. This method needs the following data to estimate the ETo: maximum and minimum temperatures, average wind speed and humidity and solar radiation (Tmax, Tmin, U, Umi and Rs, respectively). One can directly input the solar radiation variable or indirectly estimate it by the daily sunshine (hours) or the Hargreaves radiation equation (02). If any of the climatic data is not available, the ETo can be estimated by either Priestley-Taylor (Tmax, Tmin, Umi, and Rs), Jesen-Haise (Tmax, Tmin, and Rs) or Hargreaves-Samani (Tmax and Tmin).

Many small and medium farmers use Class A evaporation pan for managing their irrigated crops. If that is the case, IrriFruit has a secondary screen for computing the irrigation run time with the aid of Class A pan (Figure 4), which can be accessed by pressing the Class A pan button on the toolbar (Figure 3).

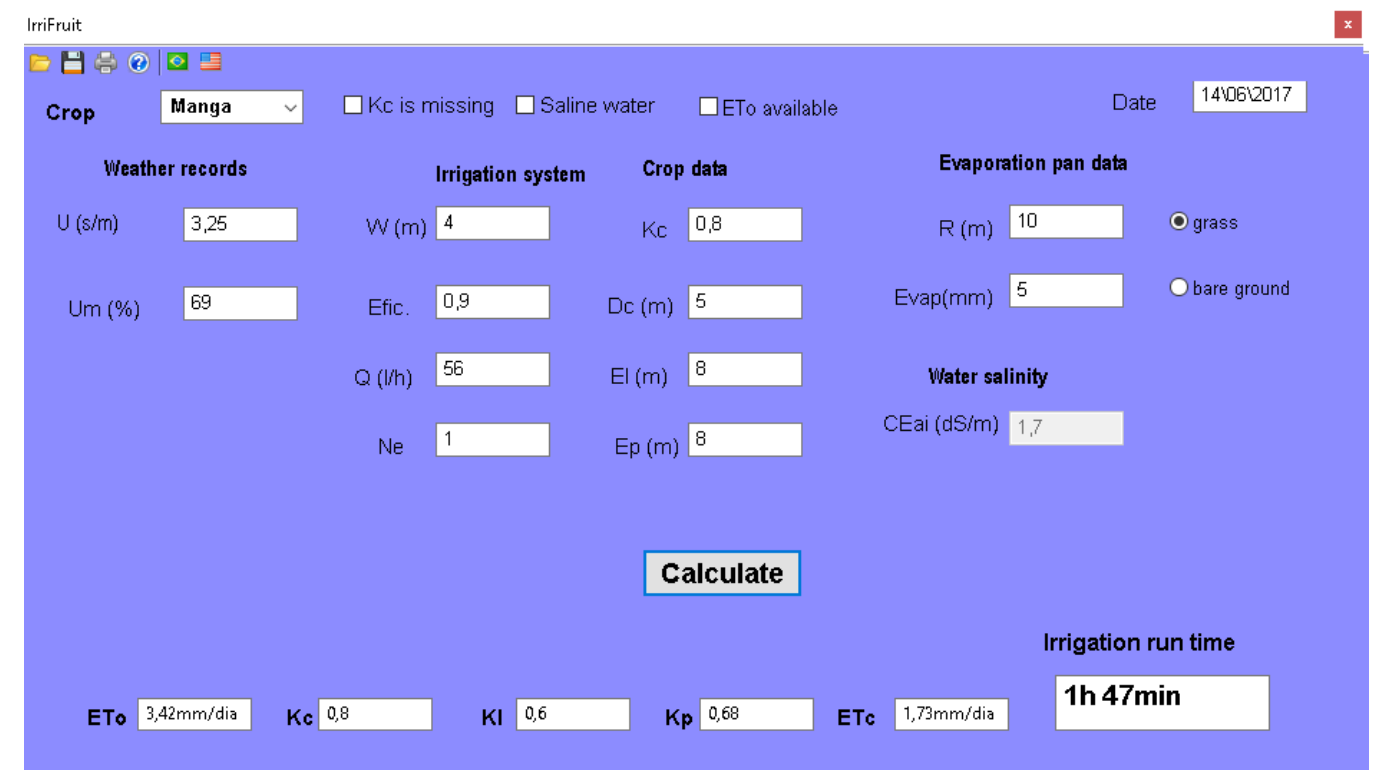

Figure 4. Secondary screen of Irrifuit for managing irrigation with the Class A pan.

If the weather station used for the weather measurements is able to estimate the ETo directly or the farmer has other ways of obtaining it, there is the option of estimating the irrigation run time without inputting any weather data other than the ETo (Figure 5). 


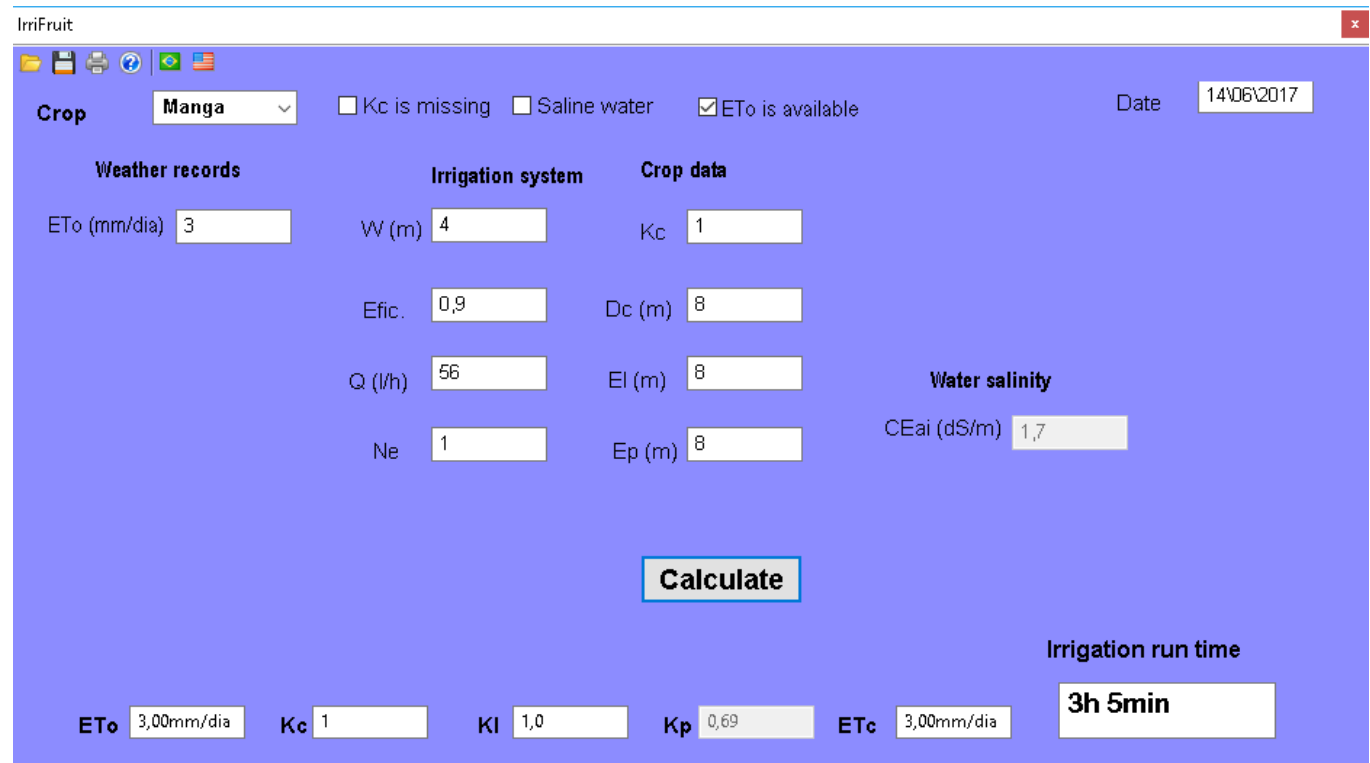

Figure 5. Secondary screen with 'ETo is available’ checkbox selected.

\section{CONCLUSIONS}

The application IrriFruit is a reliable tool for finding the right amount of water to apply when one uses localized irrigation (dripping and micro-sprinkler) to water orchards. IrriFruit can be useful for small farmers, especially those from the semiarid, who want to save money, water, and time, though it can be also used by researchers and students to easily manage their experiments in orchards.

\section{REFERENCES}

ALLEN, R. G.; SMITH, M.; PERRIER, A.; PEREIRA, L. S. An update for the definition of reference evapotranspiration. ICID Bulletin, v.43, p.01-34, 1994.

ALLEN, R.G.; PEREIRA, L.S.; RAES, D.; SMITH, M. Crop evapotranspiration: guidelines for computing crop water requirements. Rome: FAO, 1998. 370p. (FAO. Irrigation and Drainage Paper, 56).

BERNARDO, S.; SOARES, A. A.; MANTOVANI, E. C.. Manual de Irrigação. 8. ed. Viçosa: Editora UFV, 2006. v. 1. 625 p.
DOOREMBOS, J.; PRUITT, W.O. Crop water requirements. FAO - Irrigation and Drainage Paper 24. Rome, 1977. 179p.

FAO (FOOD AND AGRICULTURE ORGANIZATION OF THE UNITED NATION). Crop evapotranspiration guidelines for computing crop water requirements.FAO Irrigation and drainage paper 56. Rome, 1998. ISBN 92-5-1042105.

GOODWIN, I., BOLAND, A. M. Scheduling deficit irrigation of fruit trees for optimizing water use efficiency In. Deficit Irrigation Practices. Water Reports, n. 22, p. 67-78, 2000. Roma, FAO, 2000.

HARGREAVES, G. H.; SAMANI, Z. A. eference crop evapotranspiration from temperature. Applied Engineering

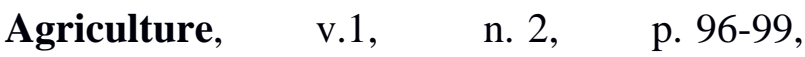
1985.

HARGREAVES, G. H.; ALLEN, R. G. History and evaluation of Hargreaves evapotranspiration equation. Journal of Irrigation and Drainage Engineering, Reston, v.129, n. 1, p.53-63, 2003. 
JENSEN, M.E.; HAISE, H.R. Estimating evapotranspiration from solar radiation. Journal of Irrigation Drainage Division, ASCE, New York, v.89, n.1, p.15-41, 1963.

MAIA, C. E.; LEVIEN, S. L. A. Estimativa de dimensões de bulbo molhado em irrigação por getejamento superficial aplicando modelo de superfície de resposta. Ciência Rural, Santa Maria, v.40, n.6, p. 1302-1308, jun. 2010.

MANTOVANI, E. C.; BERNARDO, S.; PALARETTI, L. S. Irrigação - Princípios e Métodos. 3. ed. Viçosa: Editora UFV, 2012. v. 1. 355p.

MIRANDA, F.R. Irrigacaju: Planilha Eletrônica para o Manejo da Irrigação na Produção Integrada de Caju. Fortaleza, CE: Embrapa Agroindústria Tropical, 2005. 8p. (Circular Técnica, 23).

NASCIMENTO, P.S.; BASSOI, L.H.; PAZ, V.P.S. Planilha eletrônica para auxilio à tomada de decisão em manejo de irrigação. Irriga, Botucatu-SP, v.17, n.1, p.115, jan/mar. 2012.

PAULA J.A. A.; MEDEIROS, J. F.; SOBRINHO, J. E.; CARDOSO, E. A.; MENDOÇA, V. Sistema informatizado para o manejo da irrigação na cultura da mangueira CV; Tommy Atkins' para a Chapada do Apodi. Revista Agropecuária Científica no SemiÁrido, Patos-PB, v.7, n.4, p.01-04, out/dez. 2011.
PRIESTLEY, C.H.B., TAYLOR R.J. On the assessment of surface heat flux and evaporation using large scale parameters, Mon. Weather Rev. v.100, n.2, p.81-92, 1972.

SANTOS, M. R. Irrigação com déficit hídrico controlado na cultura na mangueira no semiárido baiano. 2012. 79f. Tese (Doutorado em Engenharia Agrícola) - UFV, Viçosa.

SILVA, M. G.; ARRAES, F. D. D.; LEDO, E.R.F.; NOGUEIRA, D.H.; Desenvolvimento de planilha eletrônica para manejo de irrigação. Engenharia na Agricultura, Viçosa-MG,v.21, n.2, p.187-193, março/abril, 2013.

SILVA, V. P. R.; BELO FILHO, A. F.; SILVA, B. B.; CAMPOS. J. H. B. C. Desenvolvimento de um sistema de estimativa de evapotranspiração de referência. Revista Brasileira de Engenharia Agrícola e Ambiental, c.0, n.4, p.547-553, 2005.

SILVA, V. P. R., AZEVEDO, P. V. SILVA, B. B. Estimativa da evapotranspiração da mangueira com base no balanço hídrico do solo. Revista Brasileira de Engenharia Agrícola e Ambiental, v. 5, n. 3. p.456-462, 2001.

SMITH, M. Report on expert consultation on procedures for revision of FAO methodologies for crop water requirements. Rome, Italy: Land and Water Development Division of Food and Agriculture Organization of the United Nations, 1991. 21 p. 